\title{
ラット培養甲状腺細胞のチミジン取り込みに及ぼす メチマゾールの直接効果
}

\author{
埼玉医科大学第四内科学教室 \\ (指導：石井淳教授) \\ 卜 部 理之 \\ Thymidine Incorporation in FRTL-5 Cells
}

The Study of Direct Effect of Methimazole on

\author{
Michiyuki URABE \\ The Fourth Department of Internal Medicine, Saitama Medical School, \\ Saitama, Japan \\ (Director: Prof. Jun Ishii)
}

During the course of treatment of Graves' disease with the anti-thyroid drug, methimazole (MMI), a decrease in a patient's goiter size is sometimes observed. Using rat thyroid cell strain, FRTL-5, the direct effect of MMI on thyroid cell growth was investigated.

FRTL-5 cells $\left(2 \times 10^{5}\right)$ were cultured for 48 hours with TSH, $(\mathrm{Bu})_{2}$ cAMP or forskolin in the presence of $\left[{ }^{3} \mathrm{H}\right]$-thymidine. All three stimulators increased cell growth, expressed as $\left[{ }^{3} \mathrm{H}\right]$-thymidine incorporation into DNA in a dose-dependent fashion. When FRTL-5 cells were cultured for 48 hours in the presence of MMI at $10^{-6} \sim 10^{-3} \mathrm{M}$ with these stimulators (TSH $250 \mu \mathrm{U} / \mathrm{ml},(\mathrm{Bu})_{2} \mathrm{cAMP} 10^{-3} \mathrm{M}$, forskolin $10^{-5} \mathrm{M}$ ), $\left[{ }^{3} \mathrm{H}\right]$-thymidine incorporation was suppressed in dose-dependent fashions (MMI $10^{-5} \mathrm{M} \sim 10^{-3} \mathrm{M}$ ).

From the present study, it is suggested that methimazole directly modulates thyroid cell growth induced by thyroid growth stimulators which are involved in adenylate cyclasecyclic AMP system and that the site of its action exists beyond cAMP production.

緒

言

現在，メチマゾール (MMI) は，抗甲状腺剤として広く使用されているが，その作用機序は完全に 解明されたとはいえない。特に甲状腺細胞增殖に対するMMIの効果としてはその甲状腺ホルモン 合成抑制による血中 TSH 上昇を介しての goitrogen としての作用 ${ }^{116)}$ が考えられているにすぎな い。MMIによるグレーブス病治療中, 甲状腺腫の縮少が認められることがよく観察される ${ }^{9}$ 。筆者 は，この事実より，抗甲状腺剂自体における直接的な甲状腺細胞増殖抑制効果の存在を考え，以下 の検討を行った。即ち,ラット甲状腺培養細胞系 FRTL-5を用い, TSH， $(\mathrm{Bu})_{2} \mathrm{cAMP}$ および forskolin 等, adenylate cyclase-cAMP 細胞情報伝達系に関与する刺激物質による細胞増殖を確認した 上で，それらの増殖効果に MMI がどのような影響を与えうるかを検討した。 


\section{材料および方法}

\section{1) ラット甲状腺培養細胞, FRTL-5の培養}

今回の実験に扔いては, Fischer 系ラット甲状腺培養細胞株である FRTL-5細胞 (ATCC No. CRL1468）を用いた。FRTL-5細胞は, 通常 $25 \mathrm{~cm}^{2}$ culture bottle (Nunc) 中で $37^{\circ} \mathrm{C}, 95 \%$ air, $5 \% \mathrm{CO}_{2}$ の条件下にて単層培養を行った。培養液としては，5\% fetal bovine serum (FBS) (Hyclone) およ び細胞の成長に必要な 6 つのホルモン, 即ち TSH $1 \mathrm{mU} / \mathrm{ml}$, hydrocortisone $10 \mathrm{nM} / \mathrm{ml}$, transferrin $5 \mu \mathrm{g} / \mathrm{ml}$, glycyl-L-histidyl-L-lysine acetate $10 \mathrm{ng} / \mathrm{ml}$, somatostatin $10 \mathrm{ng} / \mathrm{ml}$ (Sigma) insulin 10 $\mu \mathrm{g} / \mathrm{ml}$ (Novo) 抢よび tobramycin $40 \mu \mathrm{g} / \mathrm{ml}$ (Shionogi) を含む Coon’s modified Ham’s F12培地 (Flow lab.) を用いた $\left(6 \mathrm{H}\right.$ 培地)。各々の実験に際しては, FRTL-5細胞 $2 \times 10^{5}$ 個を 12 wellplate (Costar) の各 well にまき, $6 \mathrm{H}$ 培地 $2 \mathrm{ml}$ にて $24 \sim 48$ 時間培養した。上清を除去後, Ham'sF12単独 培地にて 1 回洗浄後, 上清を TSH を含まない $5 \mathrm{H}+0.5 \% \mathrm{FBS}$ ( $5 \mathrm{H}$ 培地) $2 \mathrm{ml}$ に変換した。

$5 \mathrm{H}$ 培地にて 24 あるいは48時間培養 (preincubation time) 後, 各種甲状腺刺激物質を含む5H 培地 に上清を変更した。

\section{2) $\left[{ }^{3} \mathrm{H}\right]$-thymidine incorporation 測定および DNA 測定}

上清を $5 \mathrm{H}$ 培地より各種甲状腺刺激物質を含む $5 \mathrm{H}$ 培地 $2 \mathrm{ml}$ に変更, 同時に $\left[6^{-}{ }^{3} \mathrm{H}\right]$-thymidine, $2 \mu \mathrm{Ci}(\mathrm{NEN})$ を含を $5 \mathrm{H}$ 培地 $40 \mu \mathrm{l}$ を添加し，24あるいは48時間培養 (incubation time) を行った。 DNA 測定および $\left[66^{-3} \mathrm{H}\right]$-thymidine incorporation 測定は, Valente らの方法 ${ }^{29}$ に若干の変更を 加え行った。ディスパーゼ処理により細胞をプラスチック試験管に移し, PBS $3 \mathrm{ml}$ にて 2 回洗浄

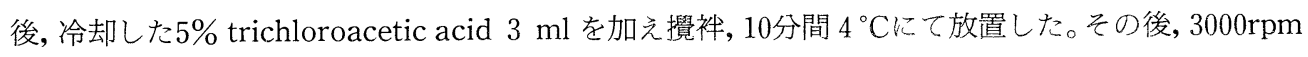
にて10分間遠心を行い, 得られた沈查に蒸留水 $1 \mathrm{ml}$ および Burton's solution (水酢酸 $100 \mathrm{ml}$ に diphenylamine $1.5 \mathrm{~g}$ を溶解, 硫酸 $1.5 \mathrm{ml}$ 抢よび $0.16 \%$ acetylaldehyde 溶液 $500 \mu 1$ を添加) $2.5 \mathrm{ml}$ を加 え, よく攪袢した。 $30^{\circ} \mathrm{C}$ に2 2 時間放置後, 分光光度計 $600 \mathrm{~nm}$ の波長で DNA を測定し, $\left[{ }^{3} \mathrm{H}\right]-$ thymidine incorporation は Burton 溶液 $1 \mathrm{ml}$ をシンチレータ $10 \mathrm{ml}$ に溶解し, 液体シンチレーショ ンカウンターにて測定した。

得られたデータの統計学的処理は Student't test にて行った。

\section{実 験 結 果}

1)TSHの $\left[{ }^{3} \mathrm{H}\right]$-thymidine incorporation への影響 (Fig. 1,2)

FRTL-5細胞増殖の指標として $\left[{ }^{3} \mathrm{H}\right]$-thymidine incorporation を測定した。前述のように $6 \mathrm{H}$ で48時間, $5 \mathrm{H}$ にて 48 時間培養後, TSH $(10 \sim 1000 \mu \mathrm{U} / \mathrm{ml})$ を含む $5 \mathrm{H}$ 培地に変換, 48 時間後に $\left[{ }^{3} \mathrm{H}\right]$-thymidine incorporation を測定した。Fig. 1に示すように TSH $50 \mu \mathrm{U} / \mathrm{ml}$ より濃度依存性 に $\left[{ }^{3} \mathrm{H}\right]$ thymidine incorporation の増加を認めた。さらにFig. 2寺すように TSH に関して, $5 \mathrm{H}$ 培地での preincubation timeの影響をみてみると, この時間が 24 時間から 48,72 時間へと長く なると, その後の TSH 再添加刺激 (incubation time) が短い24時間の群で $\left[{ }^{3} \mathrm{H}\right]$-thymidine incorporationの低下が認められた。しかし TSH 再添加刺激 (incubation time) が48時間の群では, $5 \mathrm{H}$ の preincubation time を延長したことによる $\left[{ }^{3} \mathrm{H}\right]$-thymidine incorporation の低下は消失した。

2) (BU) ${ }_{2}$ CAMP および forskolin の $\left[{ }^{3} \mathrm{H}\right]$-thymidine incorporation への影響 (Fig. 3,4)

$\mathrm{TSH}$ 添加群と同様の条件にて, $(\mathrm{Bu}){ }_{2} \mathrm{CAMP} 10^{-5} \sim 10^{-3} \mathrm{M}$, forskolin $10^{-6} \sim 10^{-4} \mathrm{M}$ の各々の濃

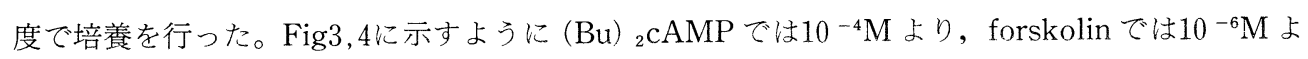




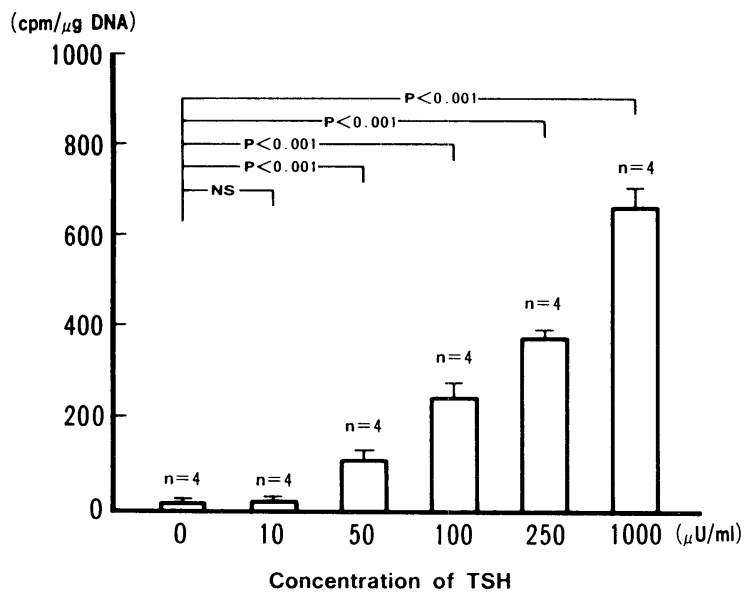

Fig. 1. Effect of TSH on $\left[{ }^{3} \mathrm{H}\right]$-Thymidine Incorporation in FRTL-5 cells in 48 hours After 48 hours of preincubation with $5 \mathrm{H}$ medium, FRTL-5 cells were incubated with TSH $0 \sim 1000 \mu \mathrm{U} / \mathrm{ml}$ in the $5 \mathrm{H}$ medium, as indicated in text, for 48 hours with $\left[6-^{3} \mathrm{H}\right]$-thymidine, $2 \mu \mathrm{Ci} /$ well. The data are mean $+\mathrm{SEM}$ of quadruplicate determinations.

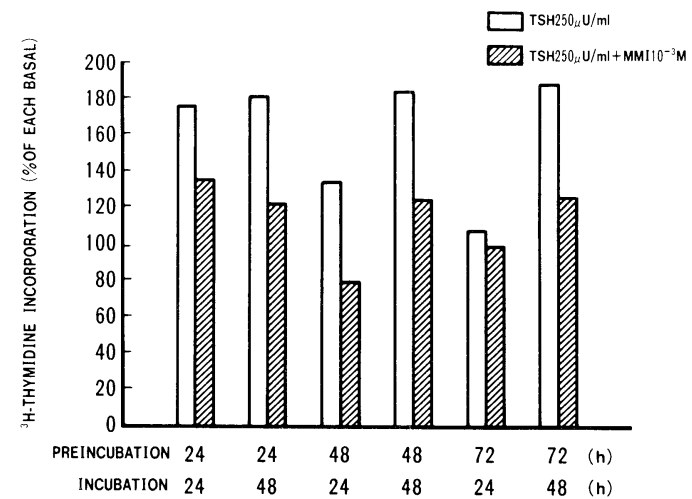

Fig. 2. Influence of Preincubation time on $\left[{ }^{3} \mathrm{H}\right]$ Thymidine Incorporation in FRTL-5 cells Induced by TSH

FRTL-5 cells plated in duplicate wells were deprived of TSH for 24,48 or 72 hours (preincubation) before the addition of TSH $250 \mu \mathrm{U} / \mathrm{ml}$ plus MMI $10^{-3} \mathrm{M}$ and $\left[6-^{3} \mathrm{H}\right]$-thymidine, $2 \mu \mathrm{Ci} /$ well. Then each group of cells were incubated for 24 or 48 hours (incubation). Each basal value of percentage is different from each group. The data were mean of duplicated determinations. 


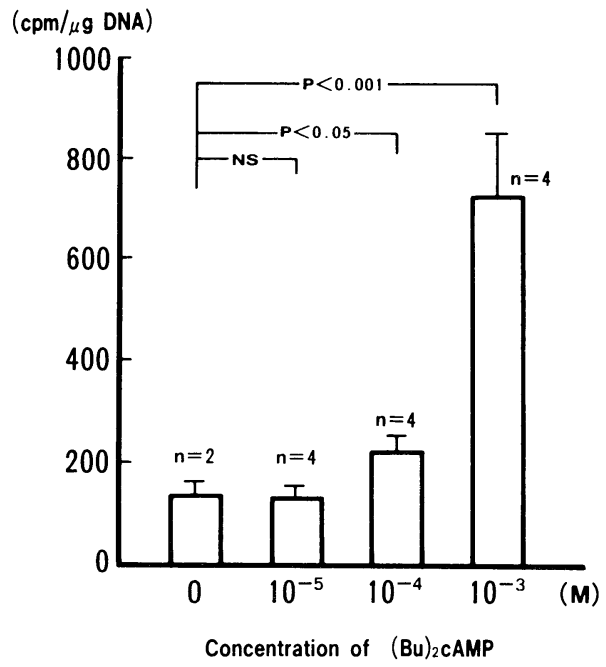

Fig. 3. Effect of $(\mathrm{Bu})_{2}$ cAMP on $\left[{ }^{3} \mathrm{H}\right]$-Thymidine Incorporation in FRTL- 5 cells in 48 hours

After 48 hours preincubation with $5 \mathrm{H}$ medium, medium were switched to $5 \mathrm{H}$ medium containing $(\mathrm{Bu})_{2}$ cAMP $0 \sim 10^{-3} \mathrm{M}$ with $\left[6-{ }^{3} \mathrm{H}\right]$ thymidine. Cells were cultured for 48 hours.

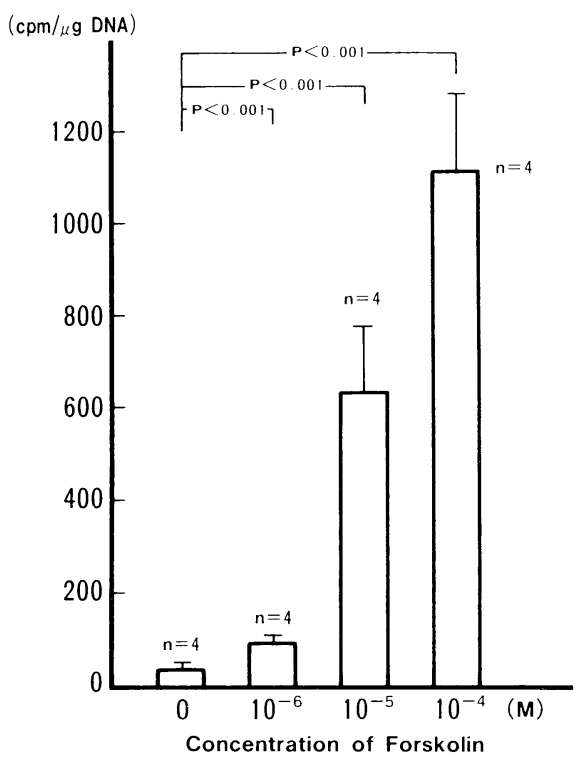

Fig. 4. Effect of Forskolin on $\left[{ }^{3} \mathrm{H}\right]$-Thymidine Incorporation in FRTL- 5 cells in 48 hours

FRTL-5 cells were cultured with forskolin $0 \sim 10^{-4} \mathrm{M}$ in the $5 \mathrm{H}$ medium with $\left[6-^{3} \mathrm{H}\right]$ thymidine after 48 hours preincubation with $5 \mathrm{H}$ medium. 
り，コントロールと比較して明かな増殖刺激効果を認めた。なお， $\left(\mathrm{Bu}{ }_{2} \mathrm{CAMP}_{2} \mathrm{CAM}^{-3} \mathrm{M}\right.$, forskolin $10^{-5} \mathrm{M}$ の濃度にて, ほほ同等の増殖刺激効果が得られたため, 以後の実験においては, こ れらの濃度を使用した。

3） TSH 刺激による [ $\left.{ }^{3} \mathrm{H}\right]$-thymidine incorporation に対する MMI の効果 (Fig. 5)

$6 \mathrm{H}$ にて48時間, $5 \mathrm{H}$ にて48時間培養後, TSH $250 \mu \mathrm{U} / \mathrm{ml}$ に MMI (Herbrand) を $10^{-3} \sim 10^{-6} \mathrm{M} て ゙$ 加えた $6 \mathrm{H}$ 培地に変換し，48時間後に $\left[{ }^{3} \mathrm{H}\right]$-thymidine incorporation を測定した。MMI10 ${ }^{-3}$ $\sim 10^{-5} \mathrm{M}$ 添加群で濃度依存性の増殖抑制効果が認められた（Fig. 5)。

データとしては示していないが，より高濃度の TSH $(500 \mu \mathrm{U} / \mathrm{ml}, 1000 \mu \mathrm{U} / \mathrm{ml})$ 添加群において MMI10 ${ }^{-3} \mathrm{M}$ を加えても, MMI の増殖抑制効果は認められなかった。また MMI の増殖抑制効果に 対して Preincubation time および incubation timeの影響は認められなかった（Fig. 2)。

4) $(\mathrm{Bu}){ }_{2} \mathrm{CAMP}$ および forskolin により誘導される $\left[{ }^{3} \mathrm{H}\right]$-thymidine incorporation に対する MMI の効果 (Fig. 6,7)。

前述の条件と同条件で培養後, $(\mathrm{Bu}){ }_{2} \mathrm{CAMP} 10^{-3} \mathrm{M}+\mathrm{MMI} 10^{-3} \sim 10^{-6} \mathrm{M}$ あるいはforskolin $10^{-5}$ $\mathrm{M}+\mathrm{MMI} 10^{-3} \sim 10^{-5} \mathrm{M}$ 各々を含む培地に変換，48時間後に $\left[{ }^{3} \mathrm{H}\right]$-thymidine incorporation を 測定した。(Bu) ${ }_{2} \mathrm{cAMP}+\mathrm{MMI}$ 添加群では, MMI10 ${ }^{-3} \sim \mathrm{MMI} 10^{-5} \mathrm{M}$ の濃度で, forskolin + MMI 添加群では MMI $10^{-3} \mathrm{M} \sim \mathrm{MMI} 10^{-4} \mathrm{M}$ の濃度で増殖抑制効果が認められた（Fig. 6,7）。

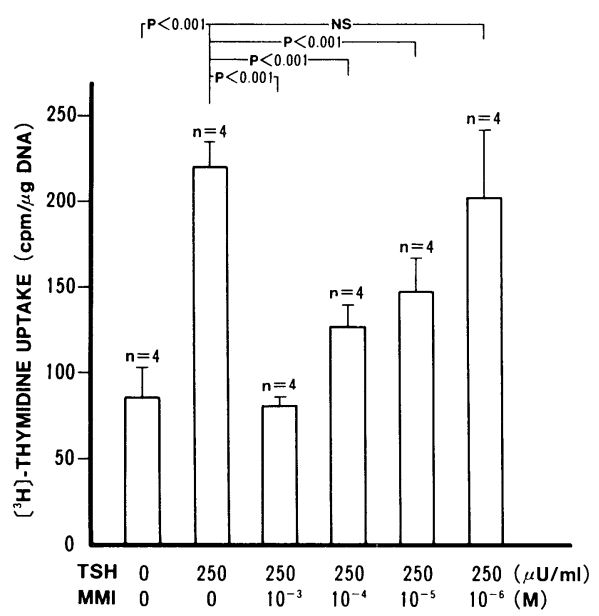

Fig. 5. Effect of MMI on TSH Induced $\left[{ }^{3} \mathrm{H}\right]$ Thymidine Incorporation in FRTL-5 cells in 48 hours

After 48 hours preincubation with $5 \mathrm{H}$ medium, FRTL-5 cells were incubated with MMI $0 \sim 10^{-3} \mathrm{M}$ in the $5 \mathrm{H}$ medium containing $\mathrm{TSH}$ $250 \mu \mathrm{U} / \mathrm{ml}$. $\left[6-^{3} \mathrm{H}\right.$ ] -thymidine, $2 \mu \mathrm{Ci} /$ well were added from the beginning of second incubation. The data were mean + SEM of quaduplicate determinations. 


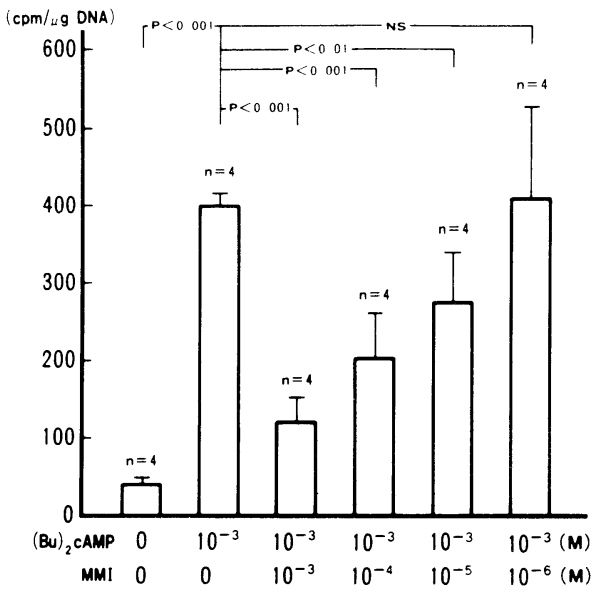

Fig. 6. Effect of MMI on $(\mathrm{Bu})_{2}$ cAMP induced $\left[{ }^{3} \mathrm{H}\right]$ Thymidine Incorporation in FRTL-5 cells in 48 hours

FRTL-5 cells were grown for 48 hours with (Bu) ${ }_{2}$ cAMP $10^{-3} \mathrm{M}+\mathrm{MMI} 10^{-3} \mathrm{M} \sim 10^{-6} \mathrm{M}$ in the presence of $\left[6{ }^{3} \mathrm{H}\right]$-thymidine, $2 \mu \mathrm{Ci} /$ well.

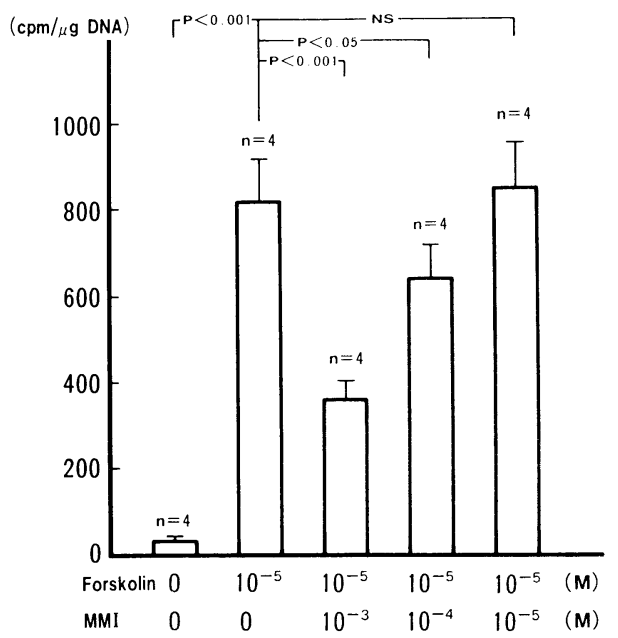

Fig. 7. Effect of MMI on forskolin induced $\left[{ }^{3} \mathrm{H}\right]$ Thymidine Incorporation in FRTL-5 cells in 48 hours

FRTL-5 cells were grown for 48 hours with forskolin $10^{-5} \mathrm{M}+\mathrm{MMI} 10^{-3} \mathrm{M} \sim 10^{-5} \mathrm{M}$ in the presence of $\left[6{ }^{3} \mathrm{H}\right]$-thymidine, $2 \mu \mathrm{Ci} /$ well. 


\section{考察}

現在, FRTL-5細胞は，正常甲状腺の機能，例えばサイログロブリン合成，ヨード取り込み等を保 ち，その増殖は TSH 依存性であることから甲状腺細胞における増殖機構を解明する上で適当な培 養細胞系と考えられている ${ }^{3)}$ 。しかしその細胞増殖の機構並びに TSH 効果の機序は, 現在不明な点 が多い。TSH は adenylate cyclase 系の活性化による cAMP 上昇を介して甲状腺細胞増殖を誘導 するという報告がある一方 ${ }^{10) 13(17) 28)}$, TSH がそのレセプターの異なる領域あるいは，他の伝達系を 介して細胞増殖を誘導するという報告 ${ }^{29}$ もあり，一致した見解は得られていない。今回の実験成績 では, TSH は50 $\mu \mathrm{U} / \mathrm{ml}$ より濃度依存性に細胞増殖促進効果を示し, 同様に cAMP の analogue で ある $(\mathrm{Bu}){ }_{2} \mathrm{cAMP}$ 添加によっても増殖促進効果がみられた。また今回筆者は adenylate cyclase 系 に直接作用し cAMPの上昇を起こすと考えられている forskolin ${ }^{726)}$ による細胞増殖効果の検討も 行い, $10^{-6} \mathrm{M}$ より濃度依存性に増殖効果を認めた。これらの成績は, 細胞増殖が adenylate cyclase 系の活性化による細胞内 cAMP の上昇により促進されることを示すとともに，TSH が cAMPを 上昇させることから, TSH の細胞増殖促進効果の一部は adenylate cyclase-cAMP 系を介すると いう説 ${ }^{32)}$ 支持するものと考えられる。

甲状腺細胞の増殖に関しては, TSH を介する adenylate cyclase 系の関与以外にもいくつかの系 の存在が示唆されている。Eggo らは ovineの thyroidの primary cultureにおいて EGF は細胞増 殖を刺激するが FRTL-5細胞においてはその刺激効果が存在せず, 理由として FRTL-5細胞におけ

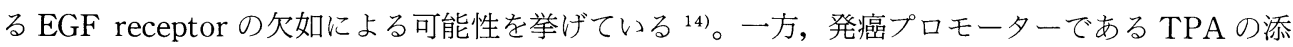
加によっても甲状腺細胞増殖が誘導されるという報告 ${ }^{5114)}$ もる。TPA の作用発現は second-messenger としての $\mathrm{Ca}^{2+}$-リン脂質依存性のプロテインキナーゼ C を介すると考えられており ${ }^{18731)}$, 甲状腺細胞増殖に関してもこの系の関与が考えられている ${ }^{2144)}$ 。今回筆者は, FRTL-5細胞増殖に関 してこれら EGF, TPA の作用の検討も行い, データは示さなかったが, EGF0.1ng/ml〜 $10 \mathrm{ng} / \mathrm{ml}$ および TPA $10^{-10} \mathrm{M} \sim 10^{-6} \mathrm{M}$ 添加によっては明かな細胞増殖効果は認められなかった。 EGFに関 しては前述の Eggo らの報告と我々の結果は一致しているが, TPA 添加により 細胞増殖が誘導され なかったことは，単に用いた FRTL-5細胞の違いによるものなのか否かは明かではない。

抗甲状腺剤, 特に今回実験に用いられたメチマゾール (MMI) は, 現在までにその作用としてヨー ド有機化の阻害 ${ }^{20)}$, サイログロブリンのヨード結合阻害によるホルモン合成阻害 ${ }^{8224227)}$, ヨードチロ シンのカップリング抑制 ${ }^{15)}$ ，サイログロブリン合成抑制 ${ }^{23}$ 抢よびその分子構造への影響 ${ }^{25) な と ゙ か ゙ ~}$ 考えられている。また最近ではその免疫系への効果，すなわち甲状腺自己抗体産生の抑制 ${ }^{22) ， ク ゙ レ ~}$

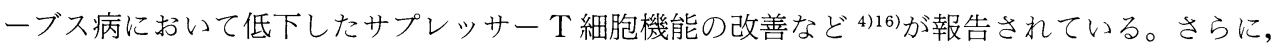
MMI は, 生体内では甲状腺ホルモン合成抑制による血中 TSH 上昇を介していわゆる goitrogen して作用する。しかし MMIによるグレーブス病治療中, 甲状腺腫が明かに縮小することがあり，こ れが寛解へ向かうよい sign であると言われている9)。甲状腺腫自体の大きさは濾胞腔の大きさ，結 合組織，脈管系の発達，濾胞上皮細胞の増殖などいくつかの因子により規定されているが，甲状腺 細胞の増殖に限ってみると, 近年, グレーブス病における甲状腺腫の発現に関して TSH レセプター を介して甲状腺細胞増殖を刺激する自己抗体 (TGI) の存在が注目されている ${ }^{11112)}$ 。Valente らは, FRTL-5細胞を用いてその検討を行った結果，未治療グレーブス病患者の $85 \%$ にその存在を認めた が，抗甲状腺剤治療にて寛解に至った患者においてはこの増殖刺激活性を認めなかったと報告して (る ${ }^{30)}$ 。抗甲状腺剤治療中, 寛解に至った患者で TGI 活性が認められなくなることは, TGI 活性の 
低下が治療中における甲状腺腫縮小の一つの因子と考えられる。

今回筆者は, グレーブス病治療経過中における甲状腺腫縮小に関して TGI 活性の低下または, 消 失以外の因子として抗甲状腺剤自体に抢ける細胞増殖抑制効果の存在を考え, MMI 添加により, FRTL-5細胞増殖がどのように修飾されるかを検討した。結果として TSH $250 \mu \mathrm{U} / \mathrm{ml}$ にて誘導され る細胞増殖は, MMI $10^{-3} \sim 10^{-5} \mathrm{M}$ の濃度で抑制され MMI が甲状腺細胞増殖に関して, 直接的に抑

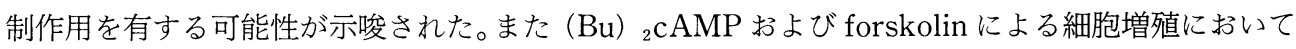
も MMIによる抑制効果が認められたことより, adenylate cyclase 系の活性化を介する細胞増殖機 構における MMI の作用点は cAMP 産生以後にあることが示唆された。しかし MMIの作用が adenylate cyclase 系以外の細胞増殖機構, すなわち $\mathrm{Ca}^{2+}$-リン脂質依存性プロテインキナーゼ C などに関与するか否かは, 今回筆者の用いた FRTL-5細胞株において TPA 添加により増殖刺激効 果を認め得なかったため検討することができなかった。またTGIにより誘導される細胞増殖に対し て MMI がやはり抑制効果を持つかどうかは興味のある所であるが, 筆者の検討したグレーブス病 症例においては，FRTL-5細胞を用いての TGI 活性を認めた例がなく検討不能であった。TGIが $\mathrm{TSAb}$ と同様に TSH レセプターに結合し, adenylate cyclase 系を活性化し cAMP 上昇を介して 細胞増殖を誘導するという説 ${ }^{17)}$ とこの実験で得た結果を考え合わせると MMI が TGIにより誘導 される甲状腺細胞増殖 (=甲状腺腫)をも抑制する可能性が考えられる。

MMI は生体内では甲状腺内で濃縮され ${ }^{21)}$, その濃度は約 $1 \sim 10 \mu \mathrm{M}$ と考えられている ${ }^{19)}$ 。今回筆 者の添加した MMI の濃度が, これらの in vivo における濃度と比較して高いことより, 薬物自体の 細胞毒性が問題となるが trypan-blue 染色による細胞の viability は95\%以上と保たれており今回 用いた濃度での MMI の細胞障害性は否定的である。実際の細胞数の検討では, [ $\left.{ }^{3} \mathrm{H}\right]$-thymidine incorporation に比較して MMI 添加による抑制は明らかではなかった。これは thymidine incorporation と実際の細胞增殖との間に存在する time lagによる可能性が考えられた。

以上の事より, MMI の甲状腺への作用が単にホルモン合成の抑制のみではなく, その細胞増殖を も抑制する可能性が示唆された。

\section{結 語}

FRTL-5細胞を用いて, その細胞増殖に関して TSH による adenylate cyclase 系の関与が存在す るか否かを検討し，その系におけるメチマゾールの直接作用について検討を行った。

1) FRTL-5細胞に扔いて $\left[{ }^{3} \mathrm{H}\right]$-thymidine incorporationにて表現される細胞増殖は，TSH (Bu) ${ }_{2} \mathrm{cAMP}$ および forskolinの添加により促進された。TSH は, adenylate cyclase 系の活性化 により甲状腺細胞増殖を刺激すると考えられた。

2）メチマゾールは, 少なくとも TSH-adenylate cyclase 系を介する FRTL-5細胞の増殖を直接 抑制する可能性が示唆され，その抑制機序は cAMP 産生よりも後のステップにあると推測された。

稿を終えるにあたり御指導と後校閲を賜りました石井淳教授に深謝し, 併せて終始直接御指導頂 きました埼玉医科大学第四内科講師原義人先生に深く感謝致します。

\section{文献}

1) Adams, A.E. and Buss, J.A.M.: The effect of a single injection of an antithyroid drug on hyperplasia in the thyroid of the chick embryo. Endocrinology, 52: 234-253, 1952. 
2) Akiguchi, I., Eguchi, K., Kawabe, Y., Otsubo, T., Miyake, S., Ishikawa, N., Ito, K., Izumi, M. and Nagataki, S.: Effect of calcium ionophore and phorbol ester on the proliferation of FRTL5 In: Vichayanrat, A., Nitiyanant, W., Eastman, C., Nagataki, S. eds. Recent progress in thyroidology. Crystal house press, Bangkok, 1987, 161-165.

3) Ambesi-Impiombato, F.S., Parks, L.A.M. and Coon, H.G.: Culture of hormone dependent functional epithelial cells from rat thyroids. Proc. Natl. Acad. Sci. USA, 77: 3455$3459,1980$.

4) Aoki, N., Pinnamaneni, K.M. and DeGroot, L.J.: Studies on suppressor cell function in thyroid disease. J. Clin. Endocrinol. Metab., 48: 803-810, 1979.

5) Bachrach, L.K., Eggo, M.C., Mak, W.W. and Burrow, G.N.: Phorbol esters stimulate growth and inhibit differentiation in cultured thyroid cells. Endocrinology, 116: 16031609, 1985.

6) Bray, G.A.: Increased sensitivity of the thyroid in iodine depleted rats to the goitrogenic effects of thyrotropin. J. Clin. Invest., 47: 1640-1647, 1968. 7) Brooker, G., Pedone, C. and Barovsky, K.: Selective reduction of forskolin-stimulated cyclic AMP accumulation by inhibitors of protein synthesis. Science, 220: 1169-1170, 1983.

8) Davidson, B., Soodak, M., Neary, J.T., Strout, H.V., Kieffer, J.D., Mover, H. and Maloof, F.: The irreversible inactivation of thyroid peroxidase by methylmercaptoimidazole, thiouracil and propylthiouracil in vitro and its relationship to in vivo findings. Endocrinology, 103: 871-882, 1978.

9) DeGroot, L.J., Lasen, P.R., Refetoff, S. and Stabury, J.B.: The thyroid and its disease, A Wiley medical publication, USA, 1984, 428.

10) Dere, W.H., Hirayu, H. and Rapoport, B.: Thyrotropin and cyclic AMP regulation of rats proto-oncogene expression in cultured thyroid cells, FEBS lett. 196: 305-308, 1986.

11) Doniach, D., Bottazzo, G.F., Khoury, E.L.: Prospects in human autoimmune thyroiditis. In: Pinchera, A., Doniach, D., Fenzi, G.F., Baschieri, L. eds. Autoimmune aspects of endcrine disorders, Academic Press, London, 1980, 25-38.

12) Drexhage, H.A., Bottazzo, G.F., Doniach, D., Bitenski, L. and Chayen, J.: Evidence for thyroid growth stimulating immunoglobulins in some goitrous thyroid disease. Lancet, 2: 287-292, 1980.

13) Ealey, P.A., Emmerson, J.M., Bidey, S.P. and Marshall, N.J.: Thyrotropin stimulation of mitogenesis of the rat thyroid cell strain FRTL-5: A metaphase index assay for the detection of thyroid growth stimulators. J. Endocr., 106: 203-210, 1985.

14) Eggo, M.C., Mak, W.W., Bachrach, L.K., Errick, J.E. and Burrow, G.N.: Cultured thyroid - Is immortality the answer? In: Eggo, M.C., Burrow, G.N. eds. Thyroglobulin The Prothyroid Hormone, Raven Press, New York, 1985, 201-210.

15) Engler, H., Taurog, A. and Dorris, M.L.: Preferential inhibition of thyroxine and 3,5,3'triiodothyronine formation by propylthiouracil and methylmercaptoimidazole in thyroid peroxidase-catalyzed iodination of thyroglobulin. Endocrinology, 110: 190-197, 1982.

16) Goldrath, N., Shoham, J., Bank, H. and Eisenstein, Z.: Anti-thyroid drugs and lymphocyte function II. The in vivo effect of blastogenesis and suppressor cell activity in Graves' disease. Clin. Exp. Immunol., 50: 62-69, 1982.

17) Jin, S., Hornicek, F.J., Neylan, D., Zakarija, M. and Mckenzie, J.M.: Evidence that adenosine $3^{\prime}, 5^{\prime}$-monophosphate 
mediates stimulation of thyroid growth in FTRL-5 cells. Endocrinology, 119: 802-810, 1986. 18) Kikkawa, U., Kaibuchi, K., Castagna, M., Yamanishi, J., Sano, K., Tanaka, Y., Miyake, R., Takai, Y. and Nishizuka, Y.: Protein phosphorylation and mechanism of action of tumor-promoting phorbol esters. In: Greengard, P., Robison, G.A., Paoletti, R., Nicosia, S. eds. Advances in Cyclic Nucleotide and Potein Phosphorylation Research 17, Raven Press, New York, 1984, 437-442.

19) Lazarus, J.H., Marchant, B., Alexander, W.D. and Clark, D.H.: ${ }^{35}$ S-antithyroid drug concentration and organic binding of iodine in the human thyroid. Clin. Endocrinol. (Oxf), 4: 609-615, 1975.

20) Maloof, F., Smith, S. and Soodak, M.: The mechanism of action of the thiocarbamide type antithyroid drugs in inhibiting iodination in thyroid tissue. Mech. React. Sulf. Comp., 4: 61-98, 1969.

21) Marchant, B., Alexander, W.D., Lazarus, J.H., Lee, J. and Clark, D.H.: The accumulation of ${ }^{35}$ S-antithyroid drugs by the thyroid gland. J. Clin. Endocrinol. Metab., 34: 847-851, $1972 . \quad 22)$ McGregor, A.M., Petersen, M.M., Mclachlan, S.M., Rooke, P., Smith, B.R. and Hall, R.: Carbimazole and the autoimmune response in Graves' disease. N. Engl. J. Med., 303: 302-307, 1980.

23) Monaco, F., Santolamazza, C., DeRos, I. and Andreoli, A.: Effect of propylthiouracil and methylmercaptoimidazole on thyroglobulin synthesis. Acta Endocrinol. 93(Copenh): 32-36, 1980.

24) Morris, D.R. and Hager, L.P.: Mechanism of the inhibition of enzymatic halogenation by antithyroid agents. J. Biol. Chem., 241: 3582-3589, 1966.

25) Papapetrou, P.D., Mothon, S. and Alexander, W.D.: Binding of the ${ }^{35} \mathrm{~S}$ of ${ }^{35}$ S-propylthiouracil by follicular thyroglobulin in vivo and in vitro. Acta Endocrinol., 79(Copenh): 248-258, $1975 . \quad 26)$ Seamon, K.B., Padgett, W. and Daly, J.W.: Forskolin: Unique diterpene activator of adenylate cyclase in membranes and in intact cells. Proc. Natl. Acad. Sci. USA, 78: 3363-3367, $1981 . \quad 27)$ Taurog, A.: The mechanism of action of thioureylene antithyroid drugs. Endocrinology, 98: 1031-1046, 1976.

28) Tramontano, D., Chin, W.W., Moses, A.C. and Ingbar, H.: Thyrotropin and dibutyryl cyclic AMP increase level of c-myc and c-fos mRNAs in cultured rat thyroid cells. J. Biol. Chem., 261: 3919-3922, $1986 . \quad$ 29) Valente, W.A., Vitti, P., Kohn, L.D., Brandi, M.L., Rotella, C.M., Toccafondi, R., Tramontano, D., Aloj, S.M. and AmbesiImpiombato, F.S.: The relationship of growth and adenylate cyclase activity in cultured thyroid cells: separate bioeffects of thyrotropin. Endocrinology, 112: 71-79, 1983.

30) Valente, W.A., Vitti, P., Rotella, C.A., Vaughan, M.M., Aloj, S.M., Grollma, E.F., Ambesi-Impiombato, F.S. and Kohn, L.D.: Antibodies that promote thyroid growth: A distinct population of thyroid stimulating autoantibodies. N. Engl. J. Med., 309: 1028 -1034, 1983. 31) Weinstein, I.B.: Protein kinase, phospholipid and control of growth. Nature, 302: 750, $1983 . \quad 32)$ Yun, K., Yamashita, S., Izumi, K., Yonemitsu, N. and Sugihara, H.: Effect of forskolin on the morphology and function of the rat thyroid cell strain, FRTL-5: Comparison with the effects of thyrotrophin. J. Endocr., 111: 397--405, 1986.

（受付日 : '87. 11. 18) 